\section{To: (Receiving Organization)}

Distribution

5. Proj./Prog./Dept./Div.:

Project W-519/Infrastructure

8. Originator Remarks:

For release

11. Receiver Remarks:

11A. Design Baseline Document? $O$ Yes

O No
4. Related EDT No.:

NA

7. Purchase Order No.

NA

9. Equip./Component No.:

NA

10. System/Bldg./Facility:

NA

12. Major Assm, Dwg. No.:

NA

13. Permit/Permit Application No.:

NA

14. Required Response Date:

NA

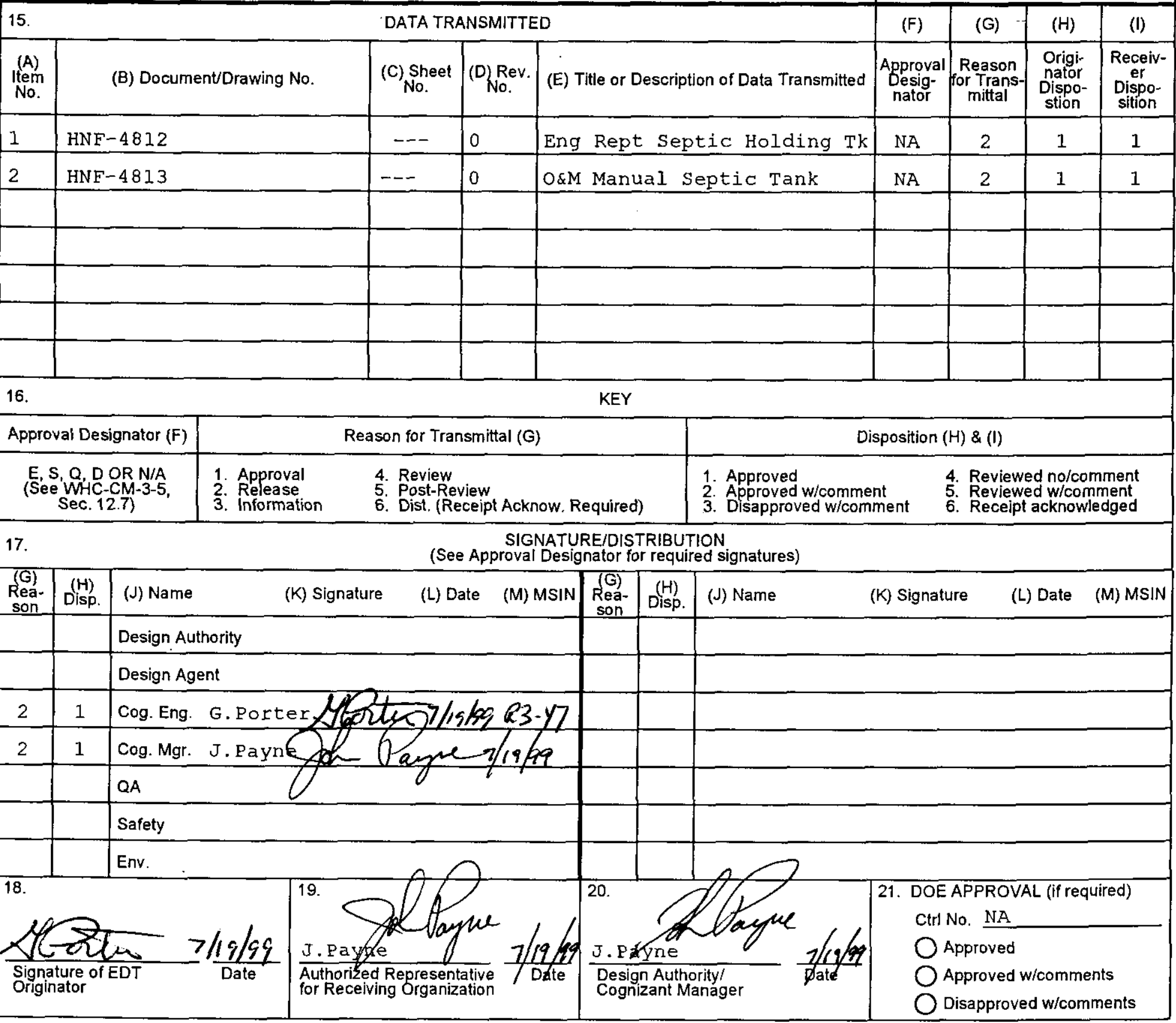




\title{
OPERATION AND MAINTENANCE MANUAL FOR SEPTIC HOLDING TANK SYSTEM FOR PROJECT W-519 CONSTRUCTION SUPPORT OFFICE TRAILERS
}

\author{
C.s.Mortimer (Fluor Daniel Northwest) \\ Numatec Hanford Corporation \\ Richland, WA 99352 \\ U.S. Department of Energy Contract DE-AC06-96RL13200

\begin{tabular}{|c|c|c|c|}
\hline EDT/ECN: & 625093 & UC: 721 & \\
\hline $\begin{array}{l}\text { Org Code: } \\
\text { B\&R Code: }\end{array}$ & 408 & $\begin{array}{l}\text { Charge Code: } \\
\text { Total Pages: }\end{array}$ & 103303 \\
\hline
\end{tabular}

Key Words: Operation and Maintenance, Project W-519, Septic Holding Tank, Privatization Infrastructure Phase I, 200E, River Protection Project

Abstract: This manual was prepared to provide detailed information for the operation and maintenance of the sanitary wastewater holding system. It sets forth system operation and maintenance as well as failure response procedures.

TRADEMARK DISCLAIMER. Reference herein to any specific commercial product, process, or service by trade name trademark, manufacturer, or otherwise, does not necessarily constitute or imply its endorsement, recommendation, or favoring by the United States Government or any agency thereof or its contractors or subcontractors.

Printed in the United States of America. To obtain copies of this document, contact: Document Control Services, P.O. Box 950, Mailstop H6-08, Richland WA 99352, Phone (509) 372-2420; Fax (509) 376-4989.

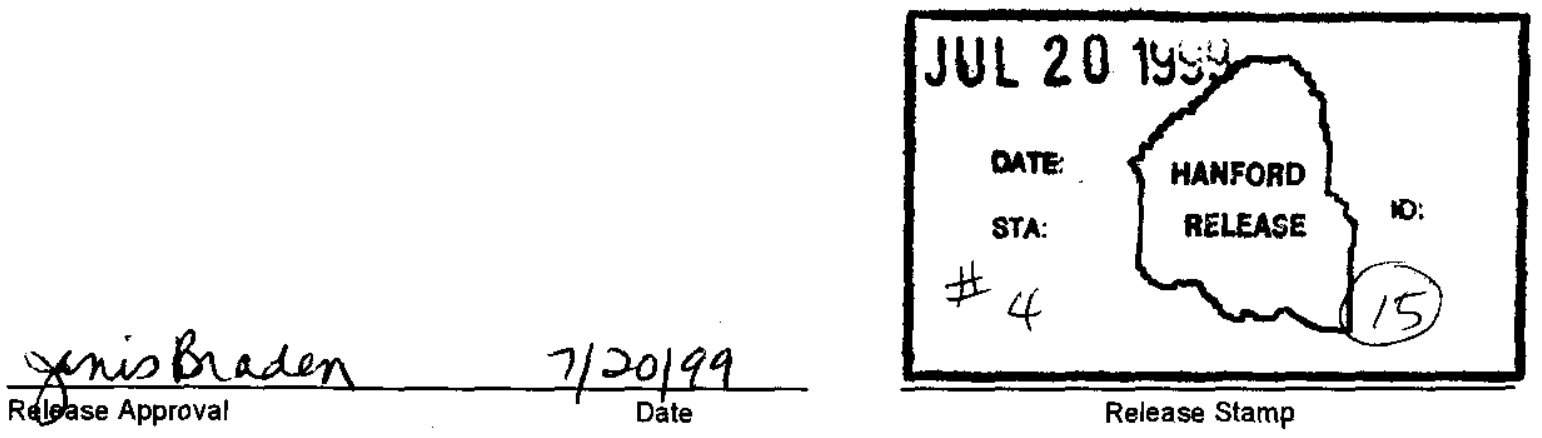

\section{Approved For Public Release}


HNF -4813

Revision 0

\title{
OPERATION AND MAINTENANCE MANUAL
}

\author{
FOR
}

SEPTIC HOLDING TANK SYSTEM

FOR PROJECT W-519

TWO DOUBLE WIDE CONSTRUCTION SUPPORT TRAILERS 


\section{APPROVAL:}

Fluor Daniel Northwest

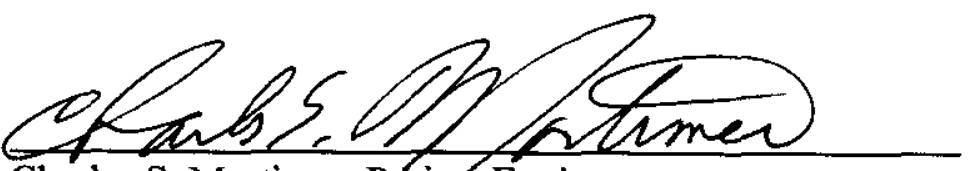

Charles S. Mortimer, Project Engineer

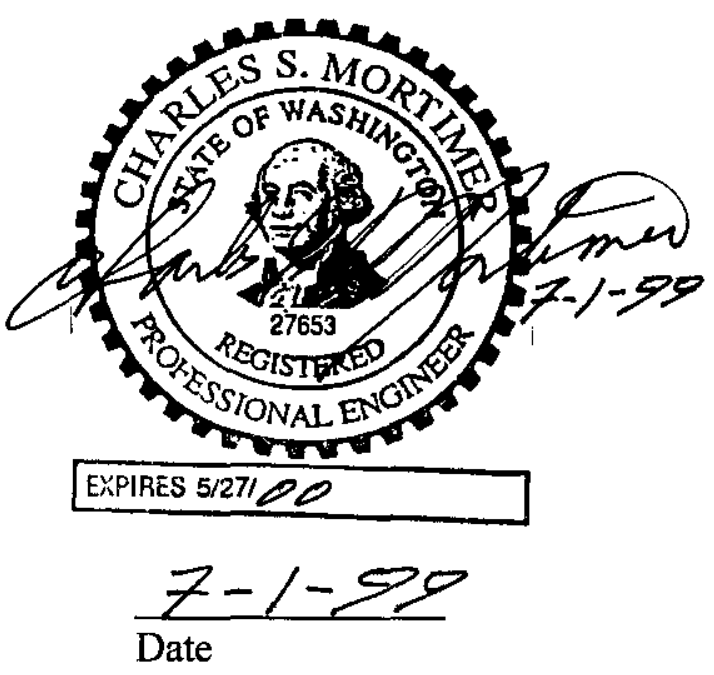

Hotenal

Projects

$\frac{2 / 12 / 99}{\text { Date }}$

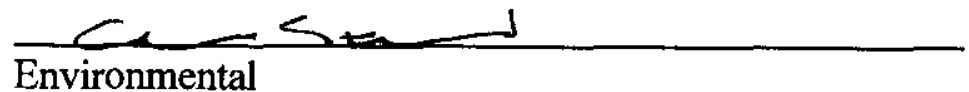

$\frac{7 / 12 / 99}{\text { Date }}$

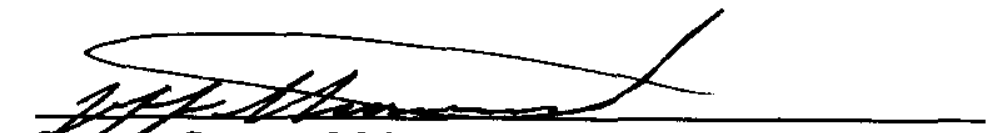

Sanifary Systems Maintenance

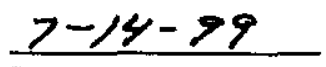

Date

Compliance with this document is required to meet Washington Administrative Code (WAC) 246-272 criteria. Any changes to this document must have the concurrence to the Washington State Department of Health and the Fluor Daniel Northwest Project Engineer. 


\section{INTRODUCTION}

This manual was prepared to provide detailed information for the operation and maintenance of the sanitary wastewater holding system. This procedure sets forth system operations which include type and frequency of required maintenance as well as system failure response procedures.

\section{SYSTEM DESCRIPTION}

The system consists of a sanitary sewage holding tank, two alarms and appurtenances necessary to provide a functional system. The maximum daily design flow is 696 liters. The holding tank is located as shown on the site plan (Appendix A).

\section{SYSTEM OPERATION}

\section{A. STANDARD OPERATING CONDITIONS}

Raw sewage enters the holding tank through the upstream collection system. Scheduled pumping occurs twice weekly.

\section{B. NONSTANDARD OPERATING CONDITIONS}

An accumulation of more than 2784 liters of effluent in the tank will produce an alarm signal. The signal is a local audible alarm and a light located on an equipment rack adjacent to the holding tank. Continued filling of an additional 2088 liters will activate a second alarm signal. This signal signifies the need to immediately notify the Manager of Sanitary Systems to initiate emergency pumping.

The first alarm signal may be caused by any or all of three events: a leaky or stuck valve (e.g. a flushometer valve or a faucet valve), an excessive use of the sanitary facilities in the trailer (e.g. extra personnel present for meeting), and/or a slip in the pumping schedule. Corrective action should commence as follows:

- $\quad$ Determine which event occurred.

- Determine if the daily wastewater load exceeds the design predictions.

- $\quad$ Based on the results of the above determinations, correct the offnormal events as follows: 
- Note the occurrence of the alarm in the log.

- $\quad$ Note the apparent reason for the occurrence.

- If the event was an anomaly to the normal operation, take no further action.

- If the event occurred due to additional personnel occupying the trailer, increase the pumping frequency to prevent a reoccurrence.

- Repair faulty/leaking plumbing.

The second alarm signal is probably the result of a slip in the pumping schedule. Correction is accomplished by maintaining the prescribed pumping schedule. It is possible that an extreme load was placed on the system in a very short period of time. Advanced planning for such an event would preclude a future occurrence.

Any nonstandard event shall be reported immediately to FDH Environmental Protection who will notify the Washington State Department of Health, W. 4th, Suite 305, Spokane, WA 99204, telephone (509) 456-2490.

\section{PERIODIC INSPECTION}

Regular inspection of essential system components is necessary to ensure the system integrity for the system design life. These periodic inspections are recorded on the Inspection Record Form (Figure 1). The inspection points are described as follows.

\section{Alarm Panel}

Float Switch Operation: Manually rotate both float switches to verify that the contacts make and break in accordance with their design function. Recover each float switch by reaching into the holding tank with a hooked rod and raise each float high enough to trip the corresponding alarm signal. This operation also verifies the proper operation of the visual $\&$ audible alarms. Should raising the floats not activate the alarms, use the "test" switch to verify the alarms are functional.

- $\quad$ The lower float switch activates the normal operating level signal

- $\quad$ The upper float activates the high liquid level signal

Submit the completed Inspection Record Form annually to FDH Environmental Protection who will forward the report to the Washington State Department of Health, W. 4th, Suite 305, Spokane, Washington 99204. 


\section{REFERENCES}

1. Preventive Maintenance Procedure, "Septic Tank Pumping," prepared by Westinghouse Hanford Company Maintenance Engineering Services, Document No. 1231, Rev 0, Change A.

2. Preventive Maintenance Procedure, "Septic Tank Inspection," prepared by Westinghouse Hanford Company Maintenance Engineering Services, Document No. 1233, Rev 0, Change A.

\section{INSPECTION RECORD FORM}

\begin{tabular}{||l|l|l|l|l|l|}
\hline ComponentTask & Frequency & Date & Date & Date \\
\hline Alarm Panel & & & & \\
\hline Check Float Switch Operation & Monthly & & & \\
\hline Manually Operate Controls & Monthly & & & \\
\hline Holding Tank & & & & \\
\hline Volume Pumped (estimate) & Every Pump & & & \\
\hline Check Inlets & Annually & & & \\
\hline
\end{tabular}

Figure 1 
HNF-4813

Revision 0

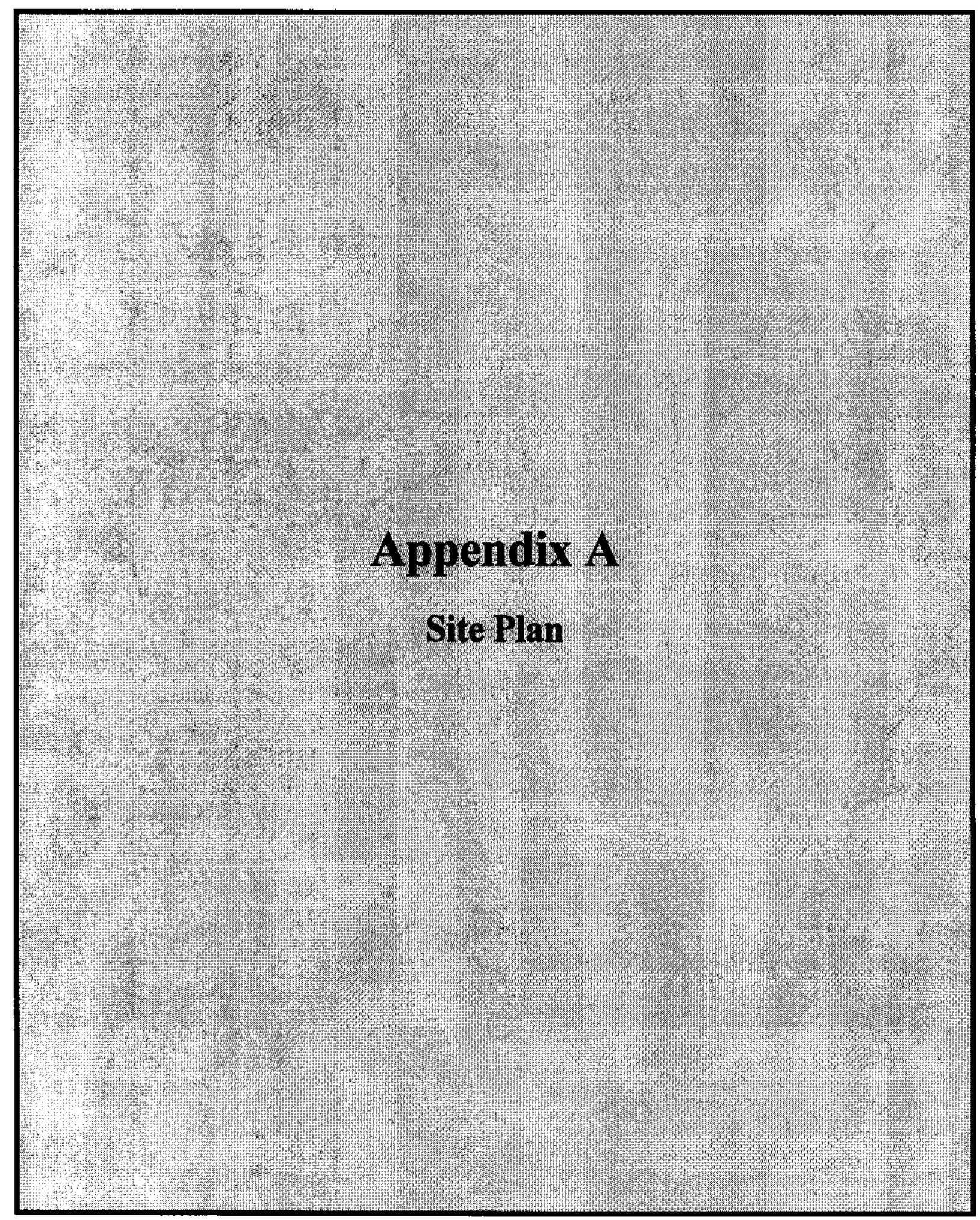

A-1 
HNF-4813

Revision 0

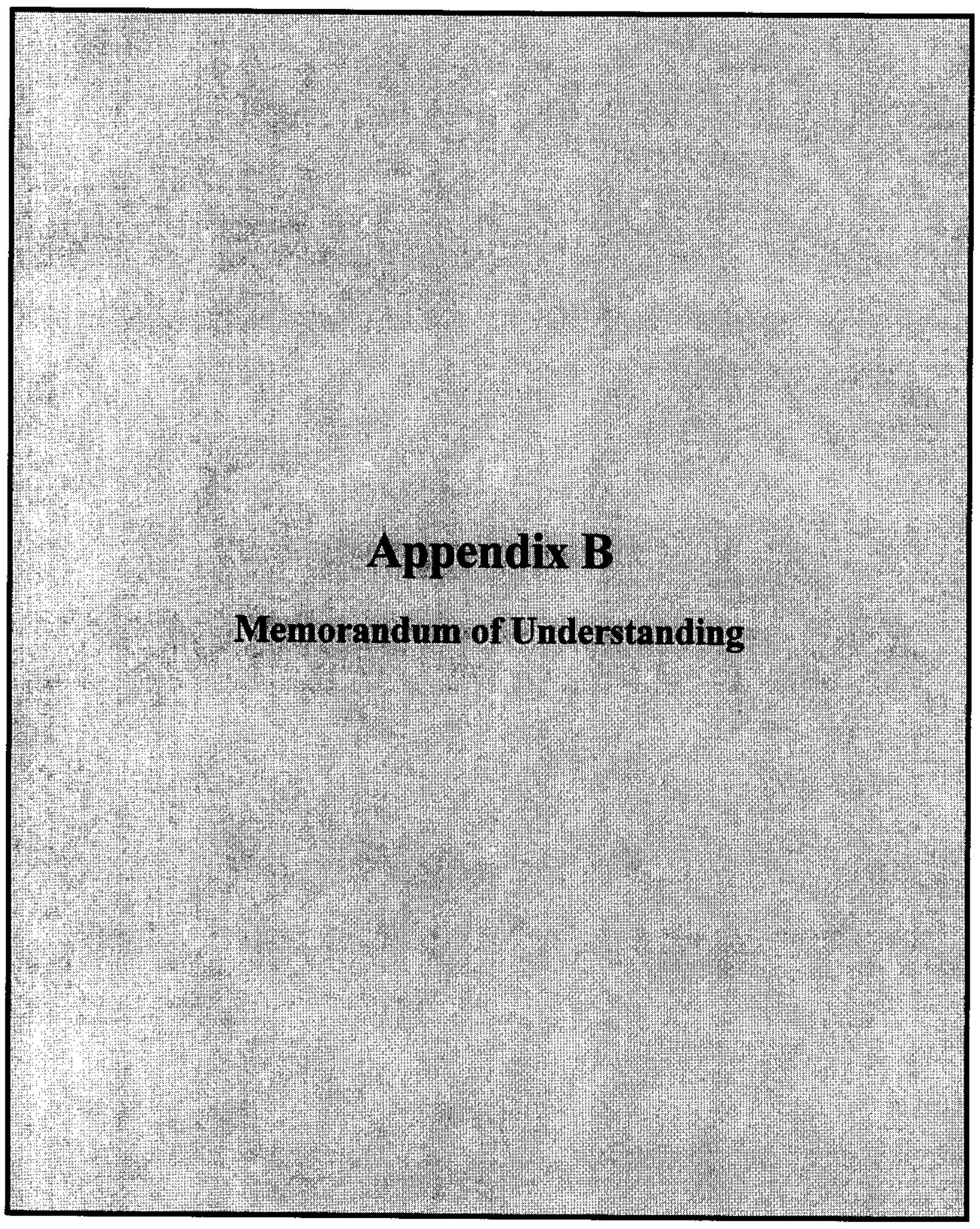

B-1 
HNF-4813

Revision 0

KH-SD-ENV-OMM-001, ReV. 0

HOLDING TANK SEAAGE SYSTEY HEMORANDUM OF UNDERSTANDING

\author{
. BETKEEH
}

THE UNITED STATES DEPARTKENT OF ENERGY, RICHLAND OPERATIOHS OFFICE

AND

THE HASHINETON STATE DEPARTMENT OF HEALTH

This Menorandum of Understanding (HOU) is between the United States, acting through the U.S. Department of Energy, Richland Operations Ofica (herainaftar referred to as $\mathrm{RL}$ ) and the Washington State Departiment of Health (hereinafter reierrad to as the $\mathrm{DOH}$ ), as the dashington Stata Departinent of Ecology designee.

$R L$ is the owner of the Haniord sita. It is the goal of the RL to conductoperations at the Haniord Sita in full complianca with apolicable environmental and public healin requirements.

$\mathrm{OOH}$ has agraed to aporove the use of saptic hoiding tanks to supgort construction/decomissioning activites on tine Hanford Site. During the operation and waintenance of the septic holding tenks, a potential exists for the uncontrolled discharge/release of ra't sewage. Such a disciarge could resuit in: 1) the contamination of suriace and groundwater, and 2) the exposure of site employess and the public to reit sewage.

It is the objective of the parties to this you to establisi and inplement appropriate procedures to assure that correct design, installation, and manacement requirements are in placa. To achieve and maintain these requirenents, the parties to this HOU understand agrea that:

1. The saptic holding tank systens on the Hanford Sita siall be designed, constructed, and managed in accordance with Nashington State Acininistrative Code (WAC) Chapter $246-272$ and the design, operation, and naintenance information contained in the "Guidelines for Holding Tank Sewage Systens" providej by the DOH Environmental Health Prograns lecinnical Reyiey Conmittee, dated Decemoer 1991. RL siall be responsiole for suoniting fiaris icr construction and management of such systems to $D O H$ for reyiew and approval consistant with requirements of WAC Chapter $246-272$.

2. RL will assure that oversight and mianagement activities conductad by contractors and/or consultants shall include compitant operation and mainienance of the temporary septic holding tank systems pursuant to HAC 246272 and the "Guidelines for Holding Tank sewage Sysiems" as provided in paragraph one (I). 
RL shall provide a copy of this MOU and releyant attachments, if any, to each of its contractors, subcontractors, and/or consultants affected by its terms. Copias of this MOU shalj be made available to all other contractors and subcontractors retained to perform work under this MOU. RL shall provide notice of this MOU to. any successor in interest prior to any transfer of ownership or operation.

This hou shall not be modified except by mutual agreement of the parties identified below. Hodification requests to the HoU siall be sant to the following points of contact:

DOE-RL: $\quad$ Annabelle L. Rodriguez, Environmental Assuranca Permits, and Policy

U.S. Department of Energy, Richland Operations Office

P.0. 550

Richland, Washington 99352

DOH: George Schlender, Larger On-Site Sewage Systan Programs

State of Washington, Department of Health

924 West Sinto

Spokane, Washington 99201

This Hemorandum of Understanding shall be efiective when signed by the two. parties, may be amended by mutual agreement, and be tarminated upon 30 days writien notica by aither party.

UNITED STATES DEPARTMENT OF ENERGY

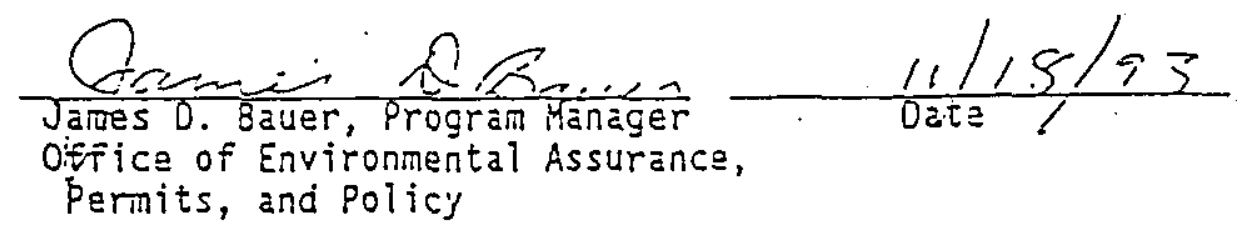

WASHINGTON STATE DEPARTMENT OF HEALTH

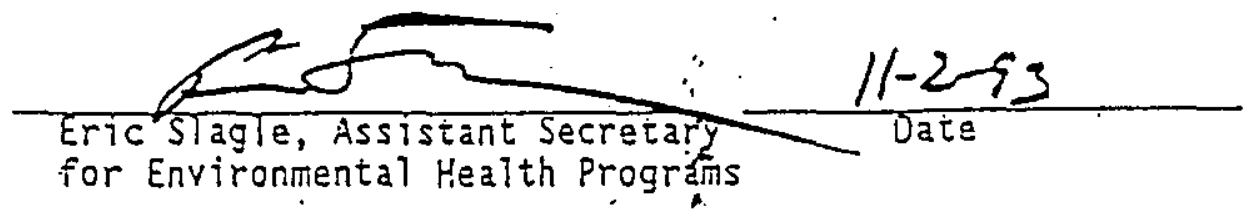


Revision 0

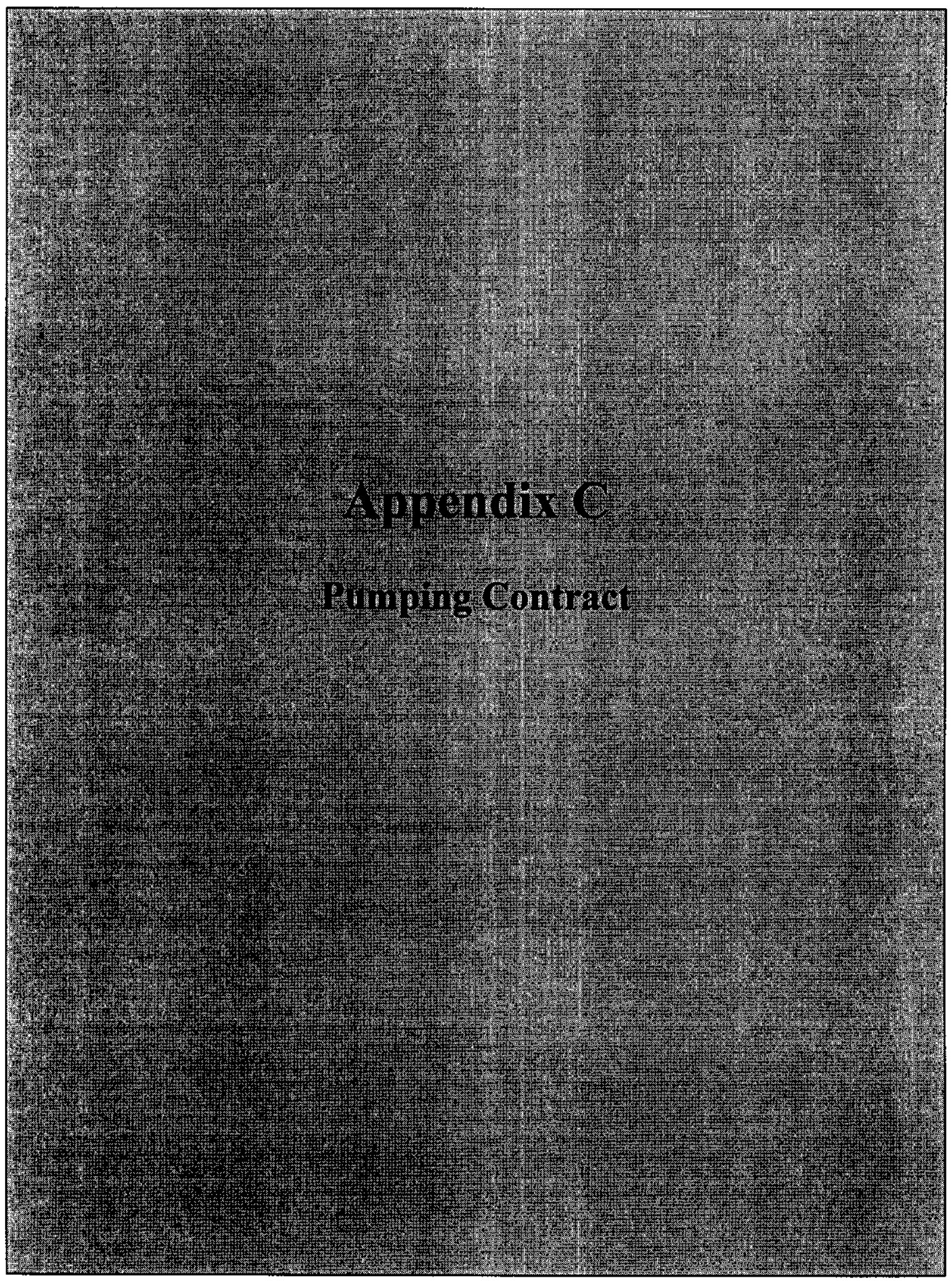


July 7, 1999

LMHC-9954673

Mr. J. A. Thornock, Manager

Sanitary Systems Maintenance T2-11

DynCorp Tri-Cities Services, Inc.

Post .Office. Box 1400

Richland, Washington 99352-1400

SUBJECT: PROJECT W-519, RIVER PROTECTION PROJECT PRIVATIZATION PHASE I INFRASTRUCTURE SUPPORT SEPTIC HOLDING TANK PUMPING SUPPORT

Dear Mr. Thornock:

This letter is to secure your organization's support for routine pumping of the Project W-5 19 septic holding tank.

The Project W-519 holding tank is located south of the 274AW facility in the 200E Area. This holding tank is approximately 6,055 liters (1,600 gallons) and has been sized based on a population of 12 full time and 6 part time personnel. Attached drawing ES-W-519-1 depicts the exact tank location.

The anticipated pumping schedule is twice a week. Pumping duration is expected to continue for approximately 30 months beginning in late July of 1999.

Your concurrence is requested for this pumping support in order to meet the requirements of the Washington State Department of Health. Please indicate your ability to support this activity by signing below. 
LMHC-9954673

Page 2

July 7, 1999

The charge code for this work is CACN 103296, COA DA00, cost center 83100.

If you have any questions concerning this effort, please call me at 372-2648.

Very truly yours

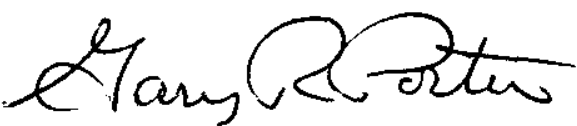

Gary R. Porter, Project Engineer

Privatization Phase I Infrastructure

Life Cycle Projects

map

Attachment

Concurrence:

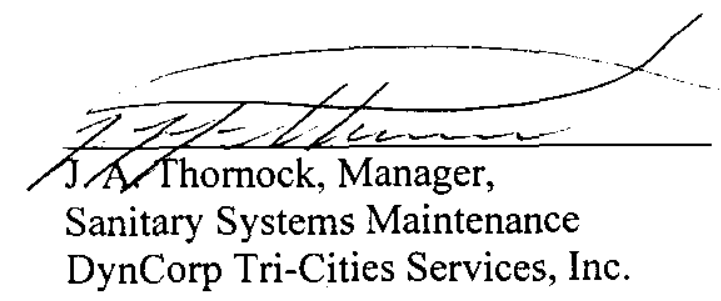




\section{DISTRIBUTION SHEET}

To

Distribution

Project Title/Work Order

Project W-519, Engineering Report Septic Holding Tank (HNF-4812) and

Operation and Maintenance Manual for Septic Holding Tank (HNF-4813)
From

G. Porter, NHC
Page 1 of 1

Date 7-19-99

EDT No. 625093

ECN No.

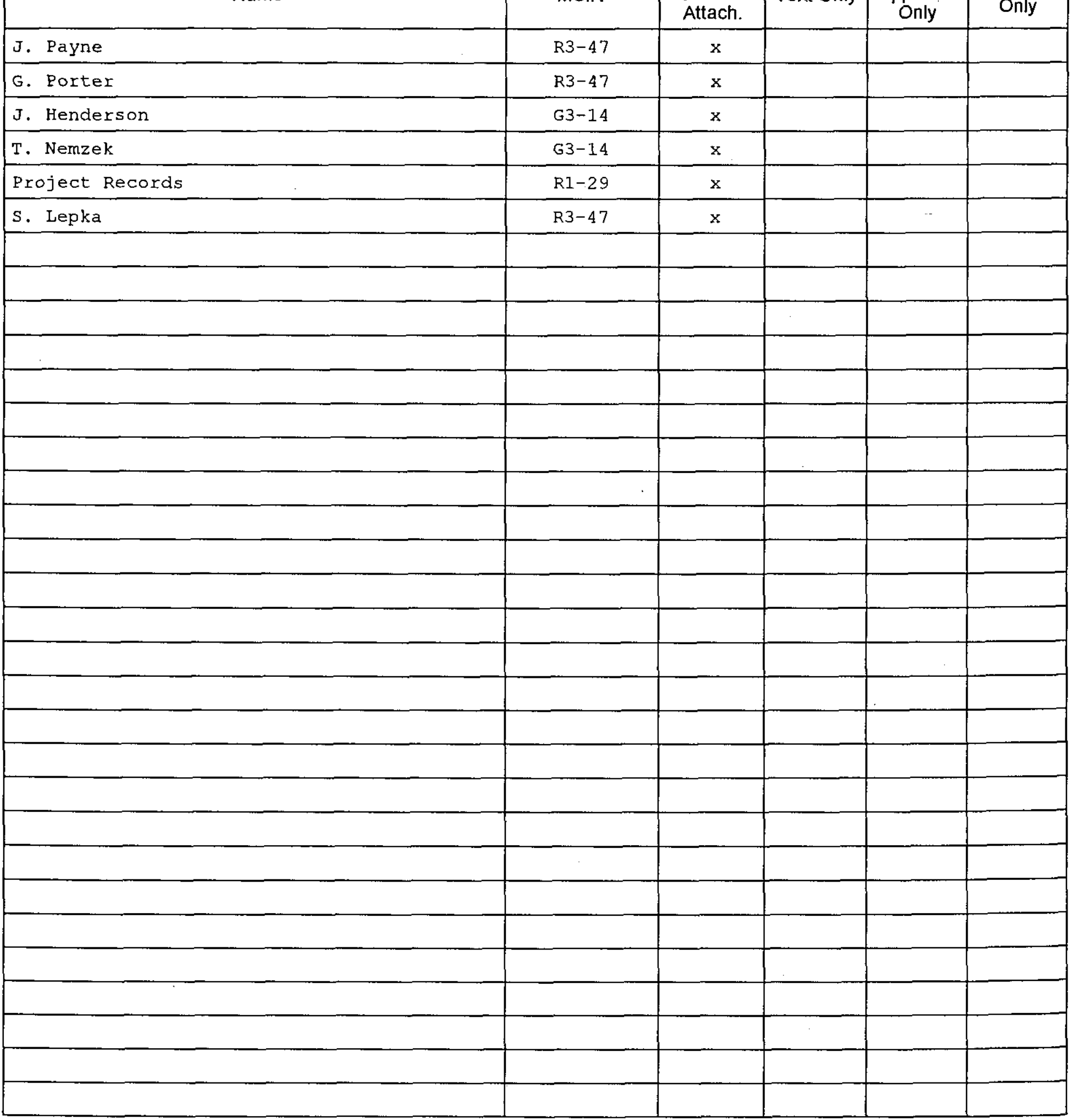

\section{Name}

\begin{tabular}{|c|c|c|c|c|} 
MSIN & $\begin{array}{c}\text { Text } \\
\text { With All } \\
\text { Attach. }\end{array}$ & Text Only & $\begin{array}{c}\text { Attach./ } \\
\text { Appendix } \\
\text { Only }\end{array}$ & $\begin{array}{c}\text { EDT/ECN } \\
\text { Only }\end{array}$ \\
\hline
\end{tabular}

J. Payne

R3-47

G3-14

63-14

R1-29

R3-47 